\title{
Suppress to Survive-Implication of Plant Viruses in PTGS
}

\author{
Przemysław Wieczorek • Aleksandra Obrẹpalska-Stẹplowska
}

Published online: 9 July 2014

(C) The Author(s) 2014. This article is published with open access at Springerlink.com

\begin{abstract}
In higher plants, evolutionarily conserved processes playing an essential role during gene expression rely on small noncoding RNA molecules (sRNA). Within a wide range of sRNA-dependent cellular events, there is posttranscriptional gene silencing, the process that is activated in response to the presence of double-stranded RNAs (dsRNAs) in planta. The sequence-specific mechanism of silencing is based on RNase-mediated trimming of dsRNAs into translationally inactive short molecules. Viruses invading and replicating in host are also a source of dsRNAs and are recognized as such by cellular posttranscriptional silencing machinery leading to degradation of the pathogenic RNA. However, viruses are not totally defenseless. In parallel with evolving plant defense strategies, viruses have managed a wide range of multifunctional proteins that efficiently impede the posttranscriptional gene silencing. These viral counteracting factors are known as suppressors of RNA silencing. The aim of this review is to summarize the role and the mode of action of several functionally characterized RNA silencing suppressors encoded by RNA viruses directly involved in plant-pathogen interactions. Additionally, we point out that the widely diverse functions, structures, and modes of action of viral suppressors can be performed by different proteins, even in related viruses. All those adaptations have been evolved to achieve the same goal: to maximize the rate of viral genetic material replication by interrupting the evolutionary conserved plant defense mechanism of posttranscriptional gene silencing.
\end{abstract}

Keywords Plant viruses · Post-transcriptional gene silencing · Suppressors of PTGS $\cdot$ Plant defense $\cdot$ Counter-defense proteins

P. Wieczorek · A. Obrępalska-Stęplowska $(\bowtie)$ Interdepartmental Laboratory of Molecular Biology, Institute of Plant Protection-National Research Institute, 20 Władysława Węorka St, 60-318 Poznań, Poland

e-mail: olaob@o2.pl

\author{
Abbreviations \\ AGO Argonaute proteins \\ DCL Dicer-like proteins \\ dsRNA Double-stranded RNA \\ miRNA MicroRNA \\ PTGS Posttranscriptional gene silencing \\ RISC RNA-induced silencing complex \\ RSS Suppressor of RNA silencing \\ sRNA Short RNA \\ siRNA Small interfering RNA
}

\section{General Overview of Posttranscriptional Gene Silencing Induced During Viral Infection}

In eukaryotes, posttranscriptional gene-silencing (PTGS) plays a pivotal role in the regulation of gene expression during development (Sunkar 2012; Wienholds and Plasterk 2005), stress feedback (Ferguson 2011) or genome stability maintenance (van Wolfswinkel and Ketting 2010). It is also induced in response to an invasion of molecular parasites, such as viruses as well as other factors similar in structure and biological properties (viroids, satellite RNAs, defecting RNAs, and defecting-interfering RNAs) (Yang et al. 2011). Although no antibodies (that would maintain stable immunological memory against viruses) have been identified in plants so far, plants utilize PTGS to efficiently and specifically recognize and eliminate those molecular pathogens. Viruses - not possessing any redundant genetic cargo - take a great advantage of cellular biochemical machinery to replicate in infected host cells. Importantly, every type of plant viruses (DNA, RNA, single (ssRNA) or double stranded, of positive or negative polarity of their genome) has to overcome the RNA stage that constitutes a source of PTGS-inducing molecules (dsRNA) (Baulcombe 2004).

Four well-defined steps can be distinguished during PTGS: (1) detection of the dsRNAs, (2) generation and amplification 
of small interfering RNAs (siRNAs), (3) silencing of viral target gene, and finally, (4) spreading of the signal between plant cells and within the host through the vasculature (Chitwood and Timmermans 2010; Kalantidis et al. 2008). dsRNAs in the cytoplasm serve as strong signaling molecules recognized by the cellular nucleases that subsequently cleave dsRNA to short (21-24 nucleotides (nt)) fragments. The nucleases, known in plants as Dicer-like proteins (DCL), belong to ribonuclease III family and have a strong affinity toward dsRNA (Liu et al. 2009).

At this point, it is important to notice that in a cell, there is also a fraction of endogenously generated primary small noncoding RNAs (reviewed in details by Axtell 2013): natural antisense transcript siRNAs (nat-siRNA), trans-acting siRNAs (ta-siRNAs), and microRNAs (miRNAs). The latter are originated from specific genomic loci described as MIR genes (discussed by Rogers and Chen 2013; Zhang et al. 2006a). The MIR genes are transcribed by RNA polymerase II in a form of long structured hairpin-containing transcripts that are subsequently put under the several processing stages dependent on DCL nucleases and methylases, among others (Axtell et al. 2011; Rogers and Chen 2013).

Among four identified in Arabidopsis thaliana DCLs, DCL4 was found to be the most involved in processing of virus-derived siRNAs. For its biochemical activity, DCL4 requires a molecular partner encoded by host plant: dsRNA-binding protein 4 (DRB4) (Fukudome et al. 2011). Interestingly, it was indicated by Ding (2010) and Llave (2010) that within overall siRNA pool, the 22-nt viral siRNAs were produced by DCL2 in the presence of DCL4, and this fraction constituted $<20 \%$ of the total viral small RNAs population. DCL1 seems to have a lesser contribution to the process (Deleris et al. 2006; Llave 2010). In triple $d c l 2$ $d c l 3 d c l 4$ A. thaliana mutant, low yet detectable level of virusderived siRNAs was identified under infection of Turnip mosaic virus, suggesting that this DCL1 can have a minor function during antiviral response (Blevins et al. 2006; Bouche et al. 2006).

The siRNAs activate the next step of the silencing described generally as RNA-dependent RNA degradation. At this stage of PTGS, siRNAs are loaded into RNA-induced silencing complex (RISC) standing in the central position of the PTGS. The nucleolytic, slicing core of the RISC complex consists of, among others, Argonaute (AGO) protein (Baumberger and Baulcombe 2005; Parker 2010; Wang et al. 2009) which, when loaded with siRNAs, undergoes scanning of target transcripts (or viral RNAs) and recognizes only those complementary with the siRNA probe. A family of ten AGO proteins was identified in Arabidopsis (Vaucheret 2008), whereas 15 AGO genes were described in Solanum lycopersicum (Bai et al. 2012; Xian et al. 2013), and nine of AGO homologs were found in the de novo-sequenced Nicotiana benthamiana transcriptome (Nakasugi et al.
2013). In A. thaliana AGO1, AGO2, AGO5, and AGO7 can bind siRNA, thus taking part in antiviral defense $(\mathrm{Qu}$ et al. 2008; Takeda et al. 2008). However, it is presumed that mainly AGO1 plays an essential role in anti-viral defense in plants (Zhang et al. 2006b), and its function might be supported by AGO2 during this process (Harvey et al. 2011). According to the authors, the $\mathrm{AGO} 2$ compensates the antiviral function of AGO1 while the former is being inhibited in a presence of PTGS suppressor. Nevertheless, Scholthof et al. stated in 2011 that AGO2 from $N$. benthamiana (NbAGO2) plays the key and specific role in the anti-Tomato bushy stunt virus (TBSV) silencing (Scholthof et al. 2011). Antiviral importance of AGO2 was then indicated in A. thaliana infected with Potato virus X (PVX) (Jaubert et al. 2011) and Turnip crinkle virus (TCV) (Zhang et al. 2012b). Additionally, antiviral function of AGO4 was proposed during Cucumber mosaic virus (CMV) infection in $N$. benthamiana (Ye et al. 2009).

Once the target messenger RNA (mRNA; or viral RNA) is identified by programmed RISC, it is either cleaved by AGO or it can be translationally unreadable (Bartel 2004; Tolia and Joshua-Tor 2007). In fact, specific protein is no longer being produced.

Moreover, primary siRNAs derived from direct DCLdependent dicing of the long dsRNA templates can promote accumulation of secondary fraction of siRNAs. This process is considered to be an amplification of PTGS signal mediated by plant RNA-dependent RNA polymerases (RDR) (Cuperus et al. 2010; Garcia-Ruiz et al. 2010; Wang et al. 2010; Wang et al. 2011) interacting with cellular suppressor of gene silencing 3 (SGS3) (Kumakura et al. 2009).

\section{Origin of Virus-Derived siRNAs}

Two major RNA elements of PTGS are required to sequencespecific inhibition of viral RNAs expression: inducer of the PTGS - dsRNA and effector molecules-siRNAs. Virus replication is restricted to specific cell compartments (den Boon and Ahlquist 2010). This spatial separation protects viral genome, at least partly, from the exposition to cellular DCLs and nucleolytic degradation. However, accumulation of dsRNA molecules, at least temporarily, was observed during multiplication of genomic RNA and transcription of subgenomic viral mRNAs. It is also strongly assumed that viral siRNAs might be derived from intramolecular fold-back structures within viral genome. This is also supported by data from deep-sequencing experiments which shows that short 20-24 nt RNAs were not distributed evenly within viral genomic RNA, and presence of characteristic sRNA hotspots (loci characterized with higher distribution of specific sRNA) was frequently observed (Aregger et al. 2012; Kalischuk et al. 2013; Mitter et al. 2013). 


\section{Approaches in the RNA Silencing Suppressors Identification}

The basic experimental identification of RNA-silencing suppressors (RSSs) was described previously by various authors (Johansen and Carrington 2001; Li and Ding 2006; Ma et al. 2009) and reviewed by Vargason et al. (2013). Three major components of the classic patch assay are required: (1) a gene to be silenced, (2) the inducer of its silencing, and (3) the studied viral protein - the putative suppressor of PTGS (Johansen and Carrington 2001). Briefly, in a presence of PTGS inducer-for instance hairpin double-stranded RNA - its target complementary mRNA (encoding a reporter gene) is efficiently silenced. However, co-expression of a PTGS suppressor stabilizes the mRNA level and the reporter gene activity. This is manifested by the intact level of reporter mRNA and barely detectable amounts of corresponding siRNAs. Conversely, lack of the suppressor leads to mRNA degradation and accumulation of siRNAs.

Moreover, silencing can occur transiently as well. This is possible because locally induced silencing, in majority of cases, is followed by systemic spread of the PTGS-inducing signals within the whole plant (Voinnet et al. 1998), which can be verified by measuring transgene expression in systemic leaves. Long-distance movement of PTGS-inducing siRNAs was also proved by an elegant experiment based on a grafting assay, where the silencing signal had been spreading from silenced rootstock into intact scion expressing marker gene (Kalantidis 2004; Mallory et al. 2001). In result, expression of reporter marker was silenced both in the rootstock and the scion. It was supposed and proved that expression of the RSS should restore activity of the silenced transgene. Similar effect is observed when RSS is expressed in plants with stably silenced reporter gene - the suppressor efficiently reverses induced PTGS, and as a result, expression of the marker is restored.

Delivery of the RSS can be done in several ways: locally (for instance by agroinfiltration), transgenetically (by transformation) (Yu et al. 2006), via crossing the silenced plant with RSS-expressing one, or by means of virus-based expressing vectors (Cao et al. 2005; Niu et al. 2009). The virus-based expressing approach was used to identify PTGS-suppressing activity of P29-a papain-like protease from Cryphonectria hypovirus 1 (Segers et al. 2006) or $\beta C 1$ from Ageratum yellow vein virus (Sharma et al. 2010). However, influence of the expressing vector itself cannot be omitted, and therefore, data delivered from such an approach must be interpreted carefully.

Most research papers describe the Agrobacterium-based transient expression tools as sufficient to verify preliminarily suppressing activity of analyzed viral proteins. This is very convenient, especially when an easily detectable, efficient, and time-saving reporter gene, for instance green fluorescent protein (GFP), is used.
To determine the exact functional abilities of RSS, further analyses are required. Assessment of RSS affinity towards siRNA or long dsRNA can be done by electrophoretic mobility shift assays (EMSA), immunoprecipitation (IP), or coimmonoprecipitation (co-IP) of the ribonucleoprotein complexes. This allows to determine the siRNA-RSS affinity and the specificity of their interactions that, together with experiments based on site-directed mutagenesis of the RSS, can provide essential information on its biological role.

In papers published by Pantaleo et al. (2007) and Csorba et al. (2010), the authors proposed a simple yet informative system, adopted and modified from a technique described previously (Parizotto et al. 2004), useful for the identification of interactions between RSS and specific miRNAs or other components of the PTGS pathway. The sensor system utilizes the in vivo transcribed engineered GFP-coding mRNA possessing a complementary miRNA target site incorporated within $3^{\prime}$ UTR of the reporter gene. In a presence of specific miRNA, molecule expression of the reporter gene is inhibited only if the sensor bears target site recognizable by the short RNA. Only specific interaction between RSS and miRNA can abolish the inhibitory potential of the short RNA, and as a result, enable expression of the reporter gene. Such a strategy, together with co-expression of candidate RSS, is an ideal tool for revealing, for instance, the miRNA turnover in the presence of a PTGS suppressor.

\section{Mechanisms of Suppression of Virus-Induced PTGS}

After the delivery of viral genetic material into the plant, PTGS machinery recognizes the pathogenic RNA, which in turn leads to its degradation. At this very stage, only immediate viral response to PTGS would enable the virus to spread systemically. In fact, this virus counteraction might be based on: (1) binding of the long dsRNA and their protection from the subsequent DCL processing, (2) sequestration and/or degradation of siRNAs, (3) inactivation of functional RISCs, (4) inhibition of short- and long-distance spread of the silencing signal. Indeed, viral suppressors can interrupt the PTGS utilizing at least one of the mentioned mechanisms.

Several examples of known RSSs were listed in Table 1 and indicated in Fig. 1. Importantly, the suppressing activity of viral proteins is shared with their other biological functions essential during virus replication cycle. This correlates with general genetic abilities of viruses: to encode only absolutely essential genes by relatively small genomes. For instance, potyviral HC-Pro is both a RSS and a helper component of viral proteinase required for virus transmission and systemic movement (Sáenz et al. 2002), whereas P38 of TCV inhibits PTGS and constitutes a component unit of viral capsid (Azevedo et al. 2010). Similarly, structural function of Tomato chlorosis virus coat 
Table 1 Examples of viral suppressors of PTGS

\begin{tabular}{|c|c|c|c|c|}
\hline Virus name (acronym) & $\begin{array}{l}\text { Identified } \\
\text { RSS }\end{array}$ & Biological function & $\begin{array}{l}\text { Proposed mechanism of PTGS } \\
\text { suppression }\end{array}$ & References \\
\hline $\begin{array}{l}\text { Tobacco mosaic virus } \\
\text { (TMV) }\end{array}$ & P126 & $\begin{array}{l}\text { Multidomain protein with } \\
\text { helicase and methyltransferase } \\
\text { activities; RNA genome } \\
\text { replication, viral cell-to-cell } \\
\text { movement }\end{array}$ & $\begin{array}{l}\text { HEL, MET, and NONII domains } \\
\text { with RSS activity, binds siRNA } \\
\text { in size-selective manner }\end{array}$ & Wang et al. (2012) \\
\hline $\begin{array}{l}\text { Tomato aspermy virus } \\
\text { (TAV) }\end{array}$ & $2 b$ & Homolog of CMV 2b & $\begin{array}{l}\text { Sequestrates siRNAs, binds } \\
\text { sRNAs in length-specific and } \\
\text { sequence-independent manner }\end{array}$ & Chen et al. (2008) \\
\hline $\begin{array}{l}\text { Cucumber mosaic virus } \\
\text { (CMV) }\end{array}$ & $2 b$ & $\begin{array}{l}\text { Symptom induction, virulence } \\
\text { determinant, host-specific } \\
\text { virus accumulation }\end{array}$ & $\begin{array}{l}\text { Sequestrates long and short } \\
\text { dsRNAs, interacts with AGO1, } \\
\text { interacts with AGO4 }\end{array}$ & $\begin{array}{l}\text { Zhang et al. (2006b) } \\
\text { and Gonzalez et al. } \\
\text { (2012) }\end{array}$ \\
\hline $\begin{array}{l}\text { Carnation Italian } \\
\text { ringspot virus } \\
(\mathrm{CIRV})\end{array}$ & P19 & $\begin{array}{l}\text { Pathogenicity determinant, } \\
\text { symptom-severity modulator }\end{array}$ & $\begin{array}{l}\text { Sequestrates siRNAs in sequence- } \\
\text { independent manner }\end{array}$ & Vargason et al. (2003) \\
\hline Potato virus $X(\mathrm{PVX})$ & P25 (TGBp1) & Cell-to-cell movement & $\begin{array}{l}\text { Interacts with } \mathrm{AGO} 1 \text { and mediates } \\
\text { its proteasome-dependent } \\
\text { degradation }\end{array}$ & Chiu et al. (2010) \\
\hline $\begin{array}{l}\text { Turnip crinkle virus } \\
\text { (TCV) }\end{array}$ & P38 & Coat protein, virion structure & $\begin{array}{l}\text { Binds and inhibits AGO1 through } \\
\text { the GW motif }\end{array}$ & Azevedo et al. (2010) \\
\hline $\begin{array}{l}\text { Barley stripe mosaic } \\
\text { virus (BSMV) }\end{array}$ & $\Gamma b$ & $\begin{array}{l}\text { Pathogenicity determinant, viral } \\
\text { long-distance movement, } \\
\text { genome amplification }\end{array}$ & $\begin{array}{l}\text { Binds ds-sRNA in size-selective } \\
\text { manner }\end{array}$ & $\begin{array}{l}\text { Yelina et al. (2002) and } \\
\text { Mérai et al. (2006) }\end{array}$ \\
\hline $\begin{array}{l}\text { Citrus leaf bloth virus } \\
\text { (CLBV) }\end{array}$ & MP & $\begin{array}{l}\text { Week PTGS suppression, local } \\
\text { function, does not inhibit cell- } \\
\text { to-cell and long movement of } \\
\text { silencing signal }\end{array}$ & Not described & Renovell et al. (2012) \\
\hline $\begin{array}{l}\text { Sweet potato mild } \\
\quad \text { mottle virus } \\
\quad(\mathrm{SPMMV})\end{array}$ & $\mathrm{P} 1$ & $\begin{array}{l}\text { Serine protease, processing of } \\
\text { viral polyprotein }\end{array}$ & $\begin{array}{l}\text { Binds to argonaute and inhibits } \\
\text { RNA-induced silencing } \\
\text { complex activity }\end{array}$ & Giner et al. (2010) \\
\hline $\begin{array}{l}\text { Cucumber vein } \\
\text { yellowing virus } \\
\text { (CVYV) }\end{array}$ & $\mathrm{P} 1 \mathrm{~b}$ & $\begin{array}{l}\text { Serine protease, processing of } \\
\text { viral polyprotein }\end{array}$ & Binds 21-nucleotide (nt) sRNAs & Valli et al. (2011) \\
\hline $\begin{array}{l}\text { Turnip mosaic virus } \\
\quad \text { (TuMV), Potato } \\
\text { virus } Y \text { (PVY) }\end{array}$ & HC-Pro & $\begin{array}{l}\text { Cysteine protease, viral } \\
\text { polyprotein processing, } \\
\text { systemic movement, } \\
\text { pathogenicity determinant }\end{array}$ & $\begin{array}{l}\text { Binds short RNAs, interacts with } \\
\text { proteasome antiviral activity }\end{array}$ & $\begin{array}{l}\text { Jin et al. (2007) and } \\
\text { Chapman et al. (2004) }\end{array}$ \\
\hline
\end{tabular}

Biological function as well as proposed implication in the PTGS was indicated

protein (CP) and P6 virion protein of Rice yellow stunt rhabdovirus is shared with its PTGS-suppressing activity (Cañizares et al. 2013; Guo et al. 2013). More interestingly, Tobacco mosaic virus $\mathrm{P} 126$ protein contains three domains: N-terminal methyltransferase (MET), two nonconserved regions (NONI and NONII), and helicase (HEL), each exhibiting independently both local and systemic PTGSsuppressing activities (Wang et al. 2012).

RNA silencing is a common process described across all kingdoms, in plant and animal systems, and consequently, suppression of it was described for plant and animal viruses. Importantly, plant viral suppressors of PTGS retain their biological function in animals, and vice versa. For instance, VP3 protein of avian Infectious bursal disease virus efficiently suppresses PTGS in plants, and can functionally replace HCPro-silencing suppressor of plant Plum pox virus (Valli et al.
2012). Maliogka et al. (2012) used the same engineered Plum pox virus potyviral background to test suppressor activity of other unrelated RSS from both plant ( $\mathrm{P} 1 \mathrm{~b}$ from Cucumber vein yellowing virus, P19 from TBSV) and animal viruses (influenza A virus NS1). Conversely, Young et al. (2012) have shown that related viruses from Potyviridae family can suppress PTGS using different proteins, and possibly, three different suppressing pathways: P1 (tritimoviruses), P1 or P1b (ipomoviruses), and HC-Pro (potyviruses).

As it will be described in the following paragraphs, the viral RSSs represent a wide biological diversity in structure, mode of action, as well as their impact on host plant. However, despite the fact that knowledge from the field of RSS is constantly verified and updated, it still seems that the fundamental mechanism of this particular virus-host interaction is yet to be discovered. New experimental data broadens and deepens the view 
Fig. 1 Examples of plant virusencoded RNA silencing suppressors and points of their action. Double-stranded RNA (dsRNA) structures can be formed during virus infection as replication intermediates or can be generated through intramolecular base pairing within genomic (or subgenomic) RNA strands (upper box). The dsRNAs are then recognized by Dicer-like proteins $(D C L)$ initiating posttranscriptional gene silencing $(P T G S)$ pathway (middle dark gray-shaded panel). Primary and secondary small interfering RNAs (siRNA) are produced and incorporated subsequently into RNA-induced silencing complex (RISC), leading to nucleolytic elimination of viral RNA. Additionally, siRNA are transported to surrounding cells what is considered as a spreading of the silencing signal (dashed arrow). However, PTGS suppressors encoded by viruses interfere with the plant defense mechanisms by interfering with different stages of the PTGS (left and right side light gray-shaded panels) and this leads to accumulation of viral genetic material and its expression in infected tissues. Examples of particular RNA silencing suppressors are indicated in hexagons pointing on their proposed silencing modes and points of action during the PTGS

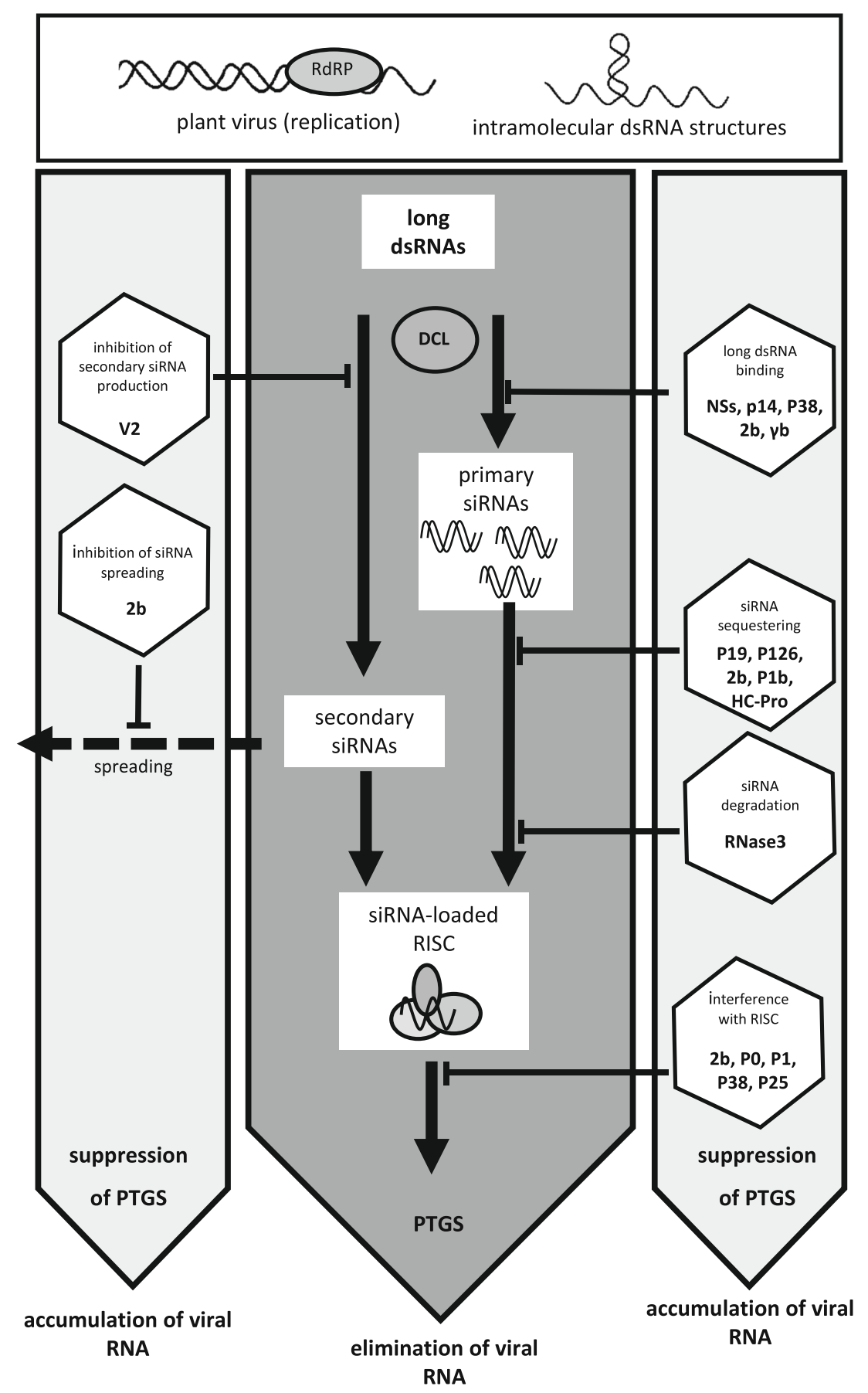

on the RSS functional complexity. It puts rather significant emphasis on the occurrence of several levels of plant defense and virus counter-defense relationships, at least at the PTGS level (reviewed on an example of 2b of CMV by Masuta and Shimura 2013 or tombusvirus P19 by Várallyay et al. 2014).

Binding of Long dsRNAs: Inhibition of the Dicing Steps

Long dsRNAs formed both locally within ssRNA segments, as well as during viral replication or produced de novo by host
RDR activate PGTS machinery. Therefore, dsRNA protection could be one of the initial steps, where suppressors guarding the viral RNAs from their DCL-dependent degradation operate. NSs suppressor of Tomato spotted wilt virus is an example of such a mechanism. The protein can efficiently bind both long and short dsRNAs (Schnettler et al. 2010) indicating that NSs activity might be situated up- or downstream of DCL dicing. Moreover, it was shown recently that PTGS-suppressing domain is located - together with hypersensitive responsetriggering avirulence determinant of the Tomato spotted wilt 
virus - within N-terminal part of NSs (de Ronde et al. 2014). Similar function of NSs was described also for other tospoviruses: Impatiens necrotic spot virus and Groundnut ringspot virus (Schnettler et al. 2010). Contrarily, another member of the family, Tomato yellow ring virus, expresses the NS that binds only short dsRNAs. The affinity of NSs suppressors of some tospoviruses to long dsRNA is not clearly understood, yet it is assumed that it might result from possible binding of the NS to hairpin elements from 3'-untranslated region of viral transcripts. This RNA-protein interaction is postulated to enhance translation of virus-derived transcripts (Geerts-Dimitriadou et al. 2012).

Binding of long dsRNAs by RSS is not limited only to tospoviruses. CP of carmovirus TCV and p14 of Pothos latent virus have an affinity to long dsRNA as well (Mérai et al. 2005, 2006).

The suppressors of the PTGS were also identified among proteins with inhibitory properties towards DCL's functionthus impairing the dicing of dsRNAs. Experimental data obtained by Cao et al. (2010) indicated that strong PTGS suppressor P38 encoded by TCV efficiently suppressed the DCL activity in A. thaliana. Interaction between DCL4 and Cauliflower mosaic virus P6 was reported to play an important role in suppression of PTGS (Haas et al. 2008).

Separation of Virus-Specific siRNAs from PTGS Machinery

\section{siRNA Sequestration}

The generalization that RSS-mediated suppression of PTGS would be based on binding of siRNAs was made by Lakatos et al. (2006). Indeed, this strategy seems to be represented by substantial number of known RSSs. For instance, tombusvirus P19 protein is a well-characterized RSS, whose function was analyzed in both plant and animal systems (Liu et al. 2012; Vargason et al. 2003). Biological activity of this suppressor depends on the generation of a stable tail-to-tail homodimer structure, which determines binding to siRNAs. The general mode of action of this RSS is based on size-specific binding of dsRNAs in a sequence-independent manner, probably by means of direct RNA binding by positively charged amino acids localized on P19 surface (Liu et al. 2012). Additionally, the affinity of the P19 was shown to be siRNAs length-dependent with the highest values for $21 \mathrm{nt}$ siRNAs (Vargason et al. 2003).

Having taken into consideration the affinity of known RSS to small RNAs, there was also a need to analyze interactions between the suppressors and microRNAs. Schnettler et al. (2010) published a paper in which the authors studied affinity of tospovirus NSs protein toward various short RNAs, including miRNAs. The authors concluded that tospoviruses interfere with PTGS by sequestering siRNAs and miRNAs molecules before they are loaded into their respective RNA-induced silencing complexes.
siRNA Degradation

As it was mentioned previously, sequestration of virus-derived siRNAs by RSS is an efficient way to suppress PTGS. However, Cuellar et al. (2009) have shown another mechanism inhibiting the process. Sweet potato chlorotic stunt virus (Cuellar et al. 2009) encodes RNase3 that binds and cleaves siRNAs into $14 \mathrm{bp}$ products that no longer can activate the RISC targeting to slice Sweet potato chlorotic stunt virus RNA. Endonucleolytic activity of the RNase3 was supported by $\mathrm{Mn}^{2+}$ and was most efficient at $\mathrm{pH} 7.5$ (long dsRNA), pH 8.5 (long and small dsRNA), and $\mathrm{pH} 8$ (Weinheimer et al. 2014).

\section{Inhibition of siRNA Transport}

Antiviral defense based on PTGS requires spreading of the silencing signal from cell to cell, and finally, within the whole plant. Therefore, suppression strategy based on inhibition of siRNAs transport might be a mechanism allowing viruses to overcome the host defense. For instance, $2 b$ protein of CMV can inhibit spreading of the silencing signal (Guo and Ding 2002). Molecular basis of siRNA binding by $2 b$ suppressor was examined in crystallographic studies of RSS encoded by another cucumovirus, Tomato aspermy virus. Studies performed by Chen et al. (2008) indicated that Tomato aspermy virus $2 \mathrm{~b}$ recognizes siRNAs by the pair of "hook-like" structures that allow the protein to bind to siRNA duplex and long dsRNA in a length-independent manner.

\section{Secondary siRNAs Synthesis Inhibition}

After recognition of dsRNA by DCL, the primary pool of siRNA is being produced. The resulting siRNAs are then subsequently loaded into the RISC leading to the production of cleaved, aberrant RNAs. Such RNAs are recognized by cellular RDRs which produce another pool of long dsRNAs out of which secondary short RNAs are diced. This stage is dependent on the interaction of two protein partners: SGS3/RDR6 (Kumakura et al. 2009; Mourrain et al. 2000; Peragine et al. 2004). SGS3 is a dsRNA-binding protein that shares specificity to the substrate with Tomato yellow leaf curl virus V2 (Fukunaga and Doudna 2009), which interacts directly with SGS3 in planta (Glick et al. 2008). The V2 outcompetes SGS3 in binding, for instance, viral dsRNA. As a result, production of the virus-derived siRNAs is inhibited (Fukunaga and Doudna 2009). Interestingly, V2 of Tomato yellow leaf curl China virus, another member of Begomovirus, possesses completely different mode of PTGS suppression: generally the protein does not interact with SGS3 and rather sequestrates siRNAs (Zhang et al. 2012a). 


\section{Alteration of Effector Complex}

One of the possible mechanisms of PTGS suppression is inactivation of the "slicer" function of the RISC core protein. As it was mentioned previously, RISC is the effector in process of the PTGS, and AGO proteins are responsible for its nucleolytic activity. In the case of $A$. thaliana, AGO1 protein plays an essential role in degradation of the target RNA. Several RSSes were found to have a direct impact on effector component of RISC. Well characterized protein $2 b$ encoded by CMV can interact with AGO1 loaded with siRNA, and inhibit its cleavage properties. Interestingly, it was reported by Hamera et al. (2012) that $2 \mathrm{~b}$ of CMV also interacts with the host plant $\mathrm{AGO} 4$ protein by recognition of its PAZ and PIWI domains counteracting AGO4-related functions during RNAdependent DNA methylation. AGO4-derived 24-nt siRNAs were found in $2 \mathrm{~b}$-sRNAs complexes, indicating that the RSS recognized the small RNAs specifically. However, as Duan et al. (2012) showed, within CMV $2 b$ there are two separate Nand $\mathrm{C}$-terminal domains responsible for dsRNA binding and AGO interaction, respectively. The siRNA-AGO-2b interactions have been revealed to be more sophisticated. The authors showed that 2b-mediated suppression of PTGS in A. thaliana is directed by $2 \mathrm{~b}$-siRNA binding, and is supported by rather than dependent on $2 \mathrm{~b}-\mathrm{AGO}$ interactions.

Baumberger and others showed (Baumberger et al. 2007; Bortolamiol et al. 2007) that a Polerovirus-encoded F-box motif of protein P0 mediates AGO1 for proteolysis and degradation. Moreover, when another member of poleroviruses, Sugarcane yellow leaf virus, has been analyzed, it displayed a surprisingly different mechanism of P0-dependent PTGS suppression. Unlike proteins $\mathrm{P}^{\mathrm{BW}}$ and $\mathrm{P} 0^{\mathrm{CA}}$, encoded by Beet western yellow virus and Cucurbit aphid-borne yellow virus, respectively, the Sugarcane yellow leaf virus $\mathrm{P} 0$ can suppress local silencing as well as systemic spread of silencing signal.

Regarding the importance of the AGO during PTGS, its function is supported by plant-encoded proteins which interact with AGO via GW/WG (glycine tryptophan/tryptophan glycine) motifs. Therefore, the question arose whether viral RSS proteins containing GW/WG motifs can inhibit PTGS via interaction with AGO. It was shown that P1 protein of Sweet potato mild mottle virus possesses three GW/WG motifs (Giner et al. 2010) that can mimic host proteins binding to AGO1-loaded RISC and thus counteract plant RNA silencing effectors. Interestingly, it was experimentally shown that Sweet potato feathery mottle virus $\mathrm{P} 1$, a GW/WG-lacking homologue of the Sweet potato mild mottle virus P1 does not possess any PTGS-suppressing activity. Two GW/WG motifs introduced experimentally into P1 converted the RSS-inactive protein into a functionally active one (Szabo et al. 2012). In the case of TCV, its multifunctional P38 was reported to compete with cellular GW/WG-containing proteins resulting in suppression of antiviral defense.

\section{RSS Involvement in Plant Pathogenicity}

The mode of action of known viral RSSs is sophisticated: it targets very sensitive plant metabolic pathways and disrupts homeostasis of cellular regulatory signals based on distribution of small regulatory RNAs. Therefore, it is not surprising that the occurrence of RSS in plant cells might be connected with macroscopic changes manifested with disease-like symptoms, for instance leaves malformation, stem stunting or local and necrotic lesions.

In a paper of Siddiqui et al. (2008), the authors analyzed phenotypic effects developed in $N$. benthamiana and $N$. tabacum stably transformed with seven viral-silencing suppressors originated from different virus genera: P1 of Rice yellow mottle virus (Sobemovirus), P1 of Cocksfoot mottle virus (Sobemovirus), P19 of TBSV (Tombusvirus), P25 of PVX (Potexvirus), HC-Pro of Potato virus Y (Potyvirus), 2b of CMV (Cucumovirus), and AC2 of African cassava mosaic virus (Begomovirus). The authors concluded that a wide range of effects manifested differently upon expression of particular RSSs with regard to transformed tobacco species. Going further, Soitamo and colleagues asked whether and how the phenotypic effect that resulted from RSS expression in plant is connected with transcriptome and proteome changes (Soitamo et al. 2011). Using both high-throughput transcriptomic (microarray) and proteomic (2-DE) approaches, the authors have shown that expression of PVY HC-Pro in transgenic plants upregulated, among others, defense-, stress-, photosynthesis-related genes. The same authors investigated cellular effect of AC2-silencing suppressor of African cassava mosaic virus expressed in transgenic tobacco (Soitamo et al. 2012). They found 1118 and 251 transcripts altered in levels in leaves and flowers, respectively. Most upregulated transcripts were associated with signaling, cell wall modifications, and stress response. When comparing the levels of altered transcripts in plants expressing HC-Pro and $\mathrm{AC} 2$, the authors concluded that ca. 500 and 300 transcripts were up- and downregulated, respectively. Additional proteomic profile of $N$. benthamiana was established by Carmo et al. (2013), who tested an influence of the AC2 of Tomato chlorotic mottle virus expressed heterologously in tobacco from PVX vector. The authors showed that AC2 disrupts a wide range of cellular mechanisms related with photosynthesis, defense or oxidative stress response, which is consistent, at least in part, with the data presented by Soitamo et al. (2012).

Going further, it was interesting whether viral RSS can modulate AGO expression and miRNA-dependent regulation. As it was shown by Várallyay et al. (2010), plant viruses induce miR168 that negatively regulates antiviral AGO1. Subsequently, Várallyay and Havelda (2013) postulated that specifically RSS-induced over-accumulation of miR168 might play an essential role in disease symptom development 
in virus infected plants. Here, the RSS would be a precise trigger that induces miR168. Indeed, using Agrobacterium-mediated transient expression assay the authors expressed different unrelated RSS (P122 of cruciferinfecting Tobamovirus, P19 of Cymbidium ringspot virus, P38 of TCV, HC-Pro of Tobacco etch virus, and 2b of CMV) in A. thaliana, and revealed over-accumulation of miR168 and downregulation of AGO1. Interestingly, it was shown that this miR168 upregulation is not dependent on P19 siRNA-binding abilities (Várallyay et al. 2014). Still, P19-3M - the P19 mutant that cannot bind siRNAs - regulates the levels of miR168 and AGO1. Additionally, although Carnation Italian ringspot virus carrying P19-3M variant accumulates in $N$. benthamiana to lower level, it still causes intermediate severity symptoms in infected plants.

Taking into consideration the interactions between miRNAs and RSS, it was shown that viral suppressors of PTGS can interfere with miRNA-mediated silencing pathways leading to developmental defects (Chapman et al. 2004; Jay et al. 2011; Shen et al. 2012; Stav et al. 2010).

\section{Concluding Remarks}

The most recent data indicate that RSSs encoded by plant viruses give an example of evolutionary molecular adaptation to the host antiviral defense. The proteins target the host plant PTGS pathways, which are responsible for efficient elimination of pathogenic RNAs from infected cells. Therefore, the dynamic equilibrium between the RSS and the PTGS components playing the crucial role in antiviral defense, determines the expansion rate of the pathogenic RNAs into the host. Additionally, even closely related viruses can have PTGSsuppressing proteins characterized by completely opposite mode of action. Moreover, no evident similarities have been found in neither protein sequence nor structure between known suppressors of PTGS. Going further, no conserved mechanisms of RSS action were noted, even though the cross-kingdom biological activity of PTGS suppressors was described. A common feature of RSS is their multifunctional character that manifests during virus replication. Some authors, however, suggest that the GW/WG motifs, as well as RNA-binding domains or positively charged amino acids localized within particular viral proteins, can predispose them to act as RSS (Bivalkar-Mehla et al. 2011). However, it is not a general rule. Thus, the identification of novel suppressors of PTGS needs to be always carried out and verified using a variety of experimental assays.

The knowledge of mechanisms of PTGS and its suppression is useful not only in a research on molecular biology of viruses. PTGS is frequently activated during transgenesis and manifests with lowered efficiency of transgene expression. Therefore, the appearance of a strong RSS can elevate the production efficiency of the recombinant protein (Gao et al. 2013; Garabagi et al. 2012; Haikonen et al. 2013; reviewed by Saunders and Lomonossoff 2013; Sun et al. 2011). However, in transgenic plants stably expressing RSS, unfavorable harmful developmental effects were observed. Saxena et al. (2011) overcame this by using modified p19 protein in the stable expression experiments. It was indicated that mutated p19p19/R43W - can serve as a RSS after it was used in the following experimental cases: in transgenic expression of p19/R43W in $N$. benthamiana, in co-expression assay (with GFP), and in CPMV (Cowpea mosaic virus) expression system (Saxena et al. 2011).

Conversely, virus-based expression vectors seem to be alternative for genetically modified organisms and the cheapest platform for synthesis of heterologous proteins in plants (Hefferon 2012; Roy et al. 2011; Yusibov et al. 2013). The high level of proteins production and considerable yield obtained from transiently transformed plants, that in fact are the cheapest source of biomass, and this speaks for using the viral expression vectors. Engineering of disarmed viral vectors that possess inactivated pathogenicity determinant(s) expressed together with a strong RSS can be considered as a very efficient tool for the production of vaccines and therapeutic proteins in plants (as reviewed by Cañizares et al. 2005).

Usefulness of RSS in biotechnology is not confined only to plant engineering. Cheng et al. (2011) found tombusviral p19 suppressor as a promising tool in the analysis of human microRNAs function. In referred study, authors showed that mutational variants of $\mathrm{p} 19$ protein, differing with single amino acid residue localized within its binding surface, can greatly increase affinity for miR122 without altering p19-siRNA interactions. Thus, they postulate that $\mathrm{p} 19$ variants can be engineered to enhance their affinity toward specific small RNAs that differ in locations of base-pair mismatches (p19s with different binding surface variants can bind various miRNAs). Schuck et al. (2013) described recapitulated AGO/RISC in vitro system that might be used as a valuable tool in studying individual components of antiviral PTGS-based defense in plants.

In summary, here we gave a brief overview on functional diversity and complexity of viral PTGS suppressors and the functions they play in plants under virus infection. However, the stream of newly described data delivered from experiments that are being constantly performed in the area of RSS, will be putting a new light on viral suppressors, the mechanism they utilize and molecular interactions during pathogenesis. In the context of the newly described results, the previously speculated molecular interactions can be interpreted differently, and in the course of time, novel biochemical and functional abilities of RSS will be characterized. This, in turn, will enrich the general knowledge about molecular biology of viruses.

Open Access This article is distributed under the terms of the Creative Commons Attribution License which permits any use, distribution, and 
reproduction in any medium, provided the original author(s) and the source are credited.

\section{References}

Aregger M, Borah BK, Seguin J, Rajeswaran R, Gubaeva EG, Zvereva AS, Windels D, Vazquez F, Blevins T, Farinelli L, Pooggin MM (2012) Primary and secondary siRNAs in geminivirus-induced gene silencing. PLoS Pathog 8:e1002941. doi:10.1371/journal.ppat. 1002941

Axtell MJ, Westholm JO, Lai EC (2011) Vive la difference: biogenesis and evolution of microRNAs in plants and animals. Genome Biol 12:221. doi:10.1186/gb-2011-12-4-221

Axtell MJ (2013) Classification and comparison of small RNAs from plants. Annu Rev Plant Biol 64:137-159. doi:10.1146/annurevarplant-050312-120043

Azevedo J, Garcia D, Pontier D, Ohnesorge S, Yu A, Garcia S, Braun L, Bergdoll M, Hakimi MA, Lagrange T, Voinnet O (2010) Argonaute quenching and global changes in Dicer homeostasis caused by a pathogen-encoded GW repeat protein. Genes Dev 24:904-915. doi: $10.1101 / \mathrm{gad} .1908710$

Bai M, Yang GS, Chen WT, Mao ZC, Kang HX, Chen GH, Yang YH, Xie BY (2012) Genome-wide identification of Dicer-like, Argonaute and RNA-dependent RNA polymerase gene families and their expression analyses in response to viral infection and abiotic stresses in Solanum lycopersicum. Gene 501:52-62. doi: 10.1016/j.gene.2012.02.009

Bartel DP (2004) MicroRNAs: genomics, biogenesis, mechanism, and function. Cell 116:281-297

Baulcombe D (2004) RNA silencing in plants. Nature 431:356-363. doi: 10.1038 /nature 02874

Baumberger N, Baulcombe DC (2005) Arabidopsis ARGONAUTE1 is an RNA Slicer that selectively recruits microRNAs and short interfering RNAs. Proc Natl Acad Sci U S A 102:11928-11933. doi:10. 1073/pnas.0505461102

Baumberger N, Tsai CH, Lie M, Havecker E, Baulcombe DC (2007) The Polerovirus silencing suppressor P0 targets ARGONAUTE proteins for degradation. Curr Biol 17:1609-1614

Bivalkar-Mehla S, Vakharia J, Mehla R, Abreha M, Kanwar JR, Tikoo A, Chauhan A (2011) Viral RNA silencing suppressors (RSS): novel strategy of viruses to ablate the host RNA interference (RNAi) defense system. Virus Res 155:1-9. doi:10.1016/j.virusres.2010. 10.003

Blevins T, Rajeswaran R, Shivaprasad PV, Beknazariants D, Si-Ammour A, Park HS, Vazquez F, Robertson D, Meins F Jr, Hohn T, Pooggin MM (2006) Four plant Dicers mediate viral small RNA biogenesis and DNA virus induced silencing. Nucleic Acids Res 34:62336246. doi:10.1093/nar/gkl886

Bortolamiol D, Pazhouhandeh M, Marrocco K, Genschik P, Ziegler-Graff V (2007) The Polerovirus F box protein P0 targets ARGONAUTE1 to suppress RNA silencing. Curr Biol 17:1615-1621

Bouche N, Lauressergues D, Gasciolli V, Vaucheret H (2006) An antagonistic function for Arabidopsis DCL2 in development and a new function for DCL4 in generating viral siRNAs. EMBO J 25:33473356. doi: $10.1038 /$ s.emboj. 7601217

Cañizares MC, Lozano-Duran R, Canto T, Bejarano ER, Bisaro DM, Navas-Castillo J, Moriones E (2013) Effects of the crinivirus coat protein-interacting plant protein SAHH on post-transcriptional RNA silencing and its suppression. Mol Plant Microbe Interact 26:10041015. doi:10.1094/MPMI-02-13-0037-R

Cañizares MC, Nicholson L, Lomonossoff GP (2005) Use of viral vectors for vaccine production in plants. Immunol Cell Biol 83:263-270. doi:10.1111/j.1440-1711.2005.01339.x
Cao M, Ye X, Willie K, Lin J, Zhang X, Redinbaugh MG, Simon AE, Morris TJ, Qu F (2010) The capsid protein of Turnip crinkle virus overcomes two separate defense barriers to facilitate systemic movement of the virus in Arabidopsis. J Virol 84:7793-7802. doi:10. 1128/JVI.02643-09

Cao X, Zhou P, Zhang X, Zhu S, Zhong X, Xiao Q, Ding B, Li Y (2005) Identification of an RNA silencing suppressor from a plant doublestranded RNA virus. J Virol 79:13018-13027. doi:10.1128/JVI.79. 20.13018-13027.2005

Carmo LS, Resende RO, Silva LP, Ribeiro SG, Mehta A (2013) Identification of host proteins modulated by the virulence factor AC2 of Tomato chlorotic mottle virus in Nicotiana benthamiana. Proteomics 13:1947-1960. doi:10.1002/pmic.201200547

Chapman EJ, Prokhnevsky AI, Gopinath K, Dolja VV, Carrington JC (2004) Viral RNA silencing suppressors inhibit the microRNA pathway at an intermediate step. Genes Dev 18:1179-1186. doi: 10.1101/gad.1201204

Chen HY, Yang J, Lin C, Yuan YA (2008) Structural basis for RNAsilencing suppression by Tomato aspermy virus protein $2 \mathrm{~b}$. EMBO Rep 9:754-760. doi:10.1038/embor.2008.118

Cheng J, Danielson DC, Nasheri N, Singaravelu R, Pezacki JP (2011) Enhanced specificity of the viral suppressor of RNA silencing protein p19 toward sequestering of human microRNA-122. Biochemistry 50:7745-7755. doi:10.1021/bi2008273

Chitwood DH, Timmermans MC (2010) Small RNAs are on the move. Nature 467:415-419. doi:10.1038/nature09351

Chiu MH, Chen IH, Baulcombe DC, Tsai CH (2010) The silencing suppressor P25 of Potato virus X interacts with Argonaute1 and mediates its degradation through the proteasome pathway. Mol Plant Pathol 11:641-649. doi:10.1111/j.1364-3703.2010.00634.x

Csorba T, Lozsa R, Hutvagner G, Burgyan J (2010) Polerovirus protein P0 prevents the assembly of small RNA-containing RISC complexes and leads to degradation of ARGONAUTE1. Plant J 62: 463-472. doi:10.1111/j.1365-313X.2010.04163.x

Cuellar WJ, Kreuze JF, Rajamaki ML, Cruzado KR, Untiveros M, Valkonen JP (2009) Elimination of antiviral defense by viral RNase III. Proc Natl Acad Sci U S A 106:10354-10358. doi:10. 1073/pnas.0806042106

Cuperus JT, Carbonell A, Fahlgren N, Garcia-Ruiz H, Burke RT, Takeda A, Sullivan CM, Gilbert SD, Montgomery TA, Carrington JC (2010) Unique functionality of 22-nt miRNAs in triggering RDR6-dependent siRNA biogenesis from target transcripts in Arabidopsis. Nat Struct Mol Biol 17:997-1003. doi:10.1038/nsmb.1866

Deleris A, Gallego-Bartolome J, Bao J, Kasschau KD, Carrington JC, Voinnet O (2006) Hierarchical action and inhibition of plant Dicerlike proteins in antiviral defense. Science 313:68-71. doi:10.1126/ science. 1128214

den Boon JA, Ahlquist P (2010) Organelle-like membrane compartmentalization of positive-strand RNA virus replication factories. Annu Rev Microbiol 64:241-256. doi:10.1146/annurev.micro.112408. 134012

de Ronde D, Pasquier A, Ying S, Butterbach P, Lohuis D, Kormelink R (2014) Analysis of Tomato spotted wilt virus NSs protein indicates the importance of the N-terminal domain for avirulence and RNA silencing suppression. Mol Plant Pathol 15:185-195. doi:10.1111/ mpp. 12082

Ding SW (2010) RNA-based antiviral immunity. Nat Rev Immunol 10: 632-644. doi:10.1038/nri2824

Duan CG, Fang YY, Zhou BJ, Zhao JH, Hou WN, Zhu H, Ding SW, Guo HS (2012) Suppression of Arabidopsis ARGONAUTE1-mediated slicing, transgene-induced RNA silencing, and DNA methylation by distinct domains of the Cucumber mosaic virus $2 \mathrm{~b}$ protein. Plant Cell 24:259-274. doi:10.1105/tpc.111.092718

Ferguson LR (2011) RNA silencing: Mechanism, biology and responses to environmental stress. Mutat Res 714:93-94. doi:10.1016/j. mrfmmm.2011.07.007 
Fukudome A, Kanaya A, Egami M, Nakazawa Y, Hiraguri A, Moriyama H, Fukuhara T (2011) Specific requirement of DRB4, a dsRNA-binding protein, for the in vitro dsRNA-cleaving activity of Arabidopsis Dicerlike 4. RNA 17:750-760. doi:10.1261/rna.2455411

Fukunaga R, Doudna JA (2009) dsRNA with 5' overhangs contributes to endogenous and antiviral RNA silencing pathways in plants. EMBO J 28:545-555. doi:10.1038/emboj.2009.2

Gao SJ, Damaj MB, Park JW, Beyene G, Buenrostro-Nava MT, Molina J, Wang X, Ciomperlik JJ, Manabayeva SA, Alvarado VY, Rathore KS, Scholthof HB, Mirkov TE (2013) Enhanced transgene expression in sugarcane by co-expression of virus-encoded RNA silencing suppressors. PLoS ONE 8:e66046. doi:10.1371/journal.pone. 0066046

Garabagi F, Gilbert E, Loos A, McLean MD, Hall JC (2012) Utility of the P19 suppressor of gene-silencing protein for production of therapeutic antibodies in Nicotiana expression hosts. Plant Biotechnol J 10:1118-1128. doi:10.1111/j.1467-7652.2012.00742.x

Garcia-Ruiz H, Takeda A, Chapman EJ, Sullivan CM, Fahlgren N, Brempelis KJ, Carrington JC (2010) Arabidopsis RNA-dependent RNA polymerases and dicer-like proteins in antiviral defense and small interfering RNA biogenesis during Turnip mosaic virus infection. Plant Cell 22:481-496. doi:10.1105/tpc.109.073056

Geerts-Dimitriadou C, Lu YY, Geertsema C, Goldbach R, Kormelink R (2012) Analysis of the Tomato spotted wilt virus ambisense S RNAencoded hairpin structure in translation. PLoS ONE 7:e31013. doi: 10.1371/journal.pone

Giner A, Lakatos L, García-Chapa M, López-Moya JJ, Burgyán J (2010) Viral protein inhibits RISC activity by Argonaute binding through conserved WG/GW motifs. PLoS Pathog 6:e1000996. doi:10.1371/ journal.ppat.1000996

Glick E, Zrachya A, Levy Y, Mett A, Gidoni D, Belausov E, Citovsky V, Gafni Y (2008) Interaction with host SGS3 is required for suppression of RNA silencing by tomato yellow leaf curl virus V2 protein. Proc Natl Acad Sci U S A 105:157-161. doi:10.1073/pnas. 0709036105

Gonzalez I, Rakitina D, Semashko M, Taliansky M, Praveen S, Palukaitis P, Carr JP, Kalinina N, Canto T (2012) RNA binding is more critical to the suppression of silencing function of Cucumber mosaic virus $2 \mathrm{~b}$ protein than nuclear localization. RNA 18:771-782. doi:10.1261/ rna.031260.111

Guo H, Song X, Xie C, Huo Y, Zhang F, Chen X, Geng Y, Fang R (2013) Rice yellow stunt rhabdovirus protein 6 suppresses systemic RNA silencing by blocking RDR6-mediated secondary siRNA synthesis. Mol Plant Microbe Interact 26:927-936. doi:10.1094/MPMI-02-130040-R

Guo HS, Ding SW (2002) A viral protein inhibits the long range signaling activity of the gene silencing signal. EMBO J 21:398-407. doi:10. 1093/emboj/21.3.398

Haas G, Azevedo J, Moissiard G, Geldreich A, Himber C, Bureau M, Fukuhara T, Keller M, Voinnet O (2008) Nuclear import of CaMV P6 is required for infection and suppression of the RNA silencing factor DRB4. EMBO J 27:2102-2112. doi:10.1038/emboj.2008.129

Haikonen T, Rajamaki ML, Valkonen JP (2013) Improved silencing suppression and enhanced heterologous protein expression are achieved using an engineered viral helper component proteinase. J Virol Methods 193:687-692. doi:10.1016/j.jviromet.2013.07.054

Hamera S, Song X, Su L, Chen X, Fang R (2012) Cucumber mosaic virus suppressor $2 \mathrm{~b}$ binds to AGO4-related small RNAs and impairs AGO4 activities. Plant J 69:104-115. doi:10.1111/j.1365-313X. 2011.04774.x

Harvey JJ, Lewsey MG, Patel K, Westwood J, Heimstadt S, Carr JP, Baulcombe DC (2011) An antiviral defense role of AGO2 in plants. PLOS ONE 6:e14639. doi:10.1371/journal.pone.0014639

Hefferon KL (2012) Plant virus expression vectors set the stage as production platforms for biopharmaceutical proteins. Virology 433:1-6. doi:10.1016/j.virol.2012.06.012
Jaubert M, Bhattacharjee S, Mello AF, Perry KL, Moffett P (2011) ARGONAUTE2 mediates RNA-silencing antiviral defenses against Potato virus X in Arabidopsis. Plant Physiol 156:1556-1564. doi:10.1104/pp. 111.178012

Jay F, Wang Y, Yu A, Taconnat L, Pelletier S, Colot V, Renou JP, Voinnet O (2011) Misregulation of AUXIN RESPONSE FACTOR 8 underlies the developmental abnormalities caused by three distinct viral silencing suppressors in Arabidopsis. PLoS Pathog 7:e1002035. doi:10.1371/journal.ppat.1002035

Jin Y, Ma D, Dong J, Jin J, Li D, Deng C, Wang T (2007) HC-Pro protein of Potato virus $\mathrm{Y}$ can interact with three Arabidopsis $20 \mathrm{~S}$ proteasome subunits in planta. J Virol 81:12881-12888. doi: 10.1128/JVI.00913-07

Johansen LK, Carrington JC (2001) Silencing on the spot. Induction and suppression of RNA silencing in the Agrobacterium-mediated transient expression system. Plant Physiol 126:930-938

Kalantidis K (2004) Grafting the way to the systemic silencing signal in plants. PLoS Biol 2:E224. doi:10.1371/journal.pbio.0020224

Kalantidis K, Schumacher HT, Alexiadis T, Helm JM (2008) RNA silencing movement in plants. Biol Cell 100:13-26. doi:10.1042/ BC20070079

Kalischuk ML, Fusaro AF, Waterhouse PM, Pappu HR, Kawchuk LM (2013) Complete genomic sequence of a Rubus yellow net virus isolate and detection of genome-wide pararetrovirus-derived small RNAs. Virus Res 178:306-313. doi:10.1016/j.virusres.2013.09.026

Kumakura N, Takeda A, Fujioka Y, Motose H, Takano R, Watanabe Y (2009) SGS3 and RDR6 interact and colocalize in cytoplasmic SGS3/RDR6-bodies. FEBS Lett 583:1261-1266. doi:10.1016/j. febslet.2009.03.055

Lakatos L, Csorba T, Pantaleo V, Chapman EJ, Carrington JC, Liu YP, Dolja VV, Calvino LF, Lopez-Moya JJ, Burgyan J (2006) Small RNA binding is a common strategy to suppress RNA silencing by several viral suppressors. EMBO J 25:2768-2780. doi:10.1038/sj. emboj.7601164

Li F, Ding SW (2006) Virus counterdefense: diverse strategies for evading the RNA-silencing immunity. Annu Rev Microbiol 60:503-531. doi:10.1146/annurev.micro.60.080805.142205

Liu Q, Feng Y, Zhu Z (2009) Dicer-like (DCL) proteins in plants. Funct Integr Genomics 9:277-286. doi:10.1007/s10142-009-0111-5

Liu X, Houzet L, Jeang KT (2012) Tombusvirus P19 RNA silencing suppressor (RSS) activity in mammalian cells correlates with charged amino acids that contribute to direct RNA-binding. Cell Biosci 2:41. doi:10.1186/2045-3701-2-41

Llave C (2010) Virus-derived small interfering RNAs at the core of plantvirus interactions. Trends Plant Sci 15:701-707. doi:10.1016/j. tplants.2010.09.001

Ma P, Liu J, He H, Yang M, Li M, Zhu X, Wang X (2009) A viral suppressor P1/HC-pro increases the GFP gene expression in agrobacterium-mediated transient assay. Appl Biochem Biotechnol 158:243-252. doi:10.1007/s12010-008-8332-y

Maliogka VI, Calvo M, Carbonell A, García JA, Valli A (2012) Heterologous RNA-silencing suppressors from both plant- and animal-infecting viruses support plum pox virus infection. J Gen Virol 93:1601-1611. doi:10.1099/vir.0.042168-0

Mallory AC, Ely L, Smith TH, Marathe R, Anandalakshmi R, Fagard M, Vaucheret H, Pruss G, Bowman L, Vance VB (2001) HC-Pro suppression of transgene silencing eliminates the small RNAs but not transgene methylation or the mobile signal. Plant Cell 13:571583

Masuta C, Shimura H (2013) RNA silencing against viruses: molecular arms race between Cucumber mosaic virus and its host. J Gen Plant Pathol 79:227-232

Mérai Z, Kerenyi Z, Kertesz S, Magna M, Lakatos L, Silhavy D (2006) Double-stranded RNA binding may be a general plant RNA viral strategy to suppress RNA silencing. J Virol 80:5747-5756. doi:10. 1128/JVI.01963-05 
Mérai Z, Kerenyi Z, Molnar A, Barta E, Valoczi A, Bisztray G, Havelda Z, Burgyan J, Silhavy D (2005) Aureusvirus P14 is an efficient RNA silencing suppressor that binds double-stranded RNAs without size specificity. J Virol 79:7217-7226. doi:10.1128/ JVI.79.11.7217-7226.2005

Mitter N, Koundal V, Williams S, Pappu H (2013) Differential expression of Tomato spotted wilt virus-derived viral small RNAs in infected commercial and experimental host plants. PLoS ONE 8:e76276. doi:10.1371/journal.pone.0076276

Mourrain P, Beclin C, Elmayan T, Feuerbach F, Godon C, Morel JB, Jouette D, Lacombe AM, Nikic S, Picault N, Remoue K, Sanial M, Vo TA, Vaucheret H (2000) Arabidopsis SGS2 and SGS3 genes are required for posttranscriptional gene silencing and natural virus resistance. Cell 101:533-542

Nakasugi K, Crowhurst RN, Bally J, Wood CC, Hellens RP, Waterhouse PM (2013) De novo transcriptome sequence assembly and analysis of RNA silencing genes of Nicotiana benthamiana. PLoS ONE 28: e59534. doi:10.1371/journal.pone.0059534

Niu S, Wang B, Guo X, Yu J, Wang X, Xu K, Zhai Y, Wang J, Liu Z (2009) Identification of two RNA silencing suppressors from Banana bunchy top virus. Arch Virol 154:1775-1783. doi:10. 1007/s00705-009-0515-5

Pantaleo V, Szittya G, Burgyan J (2007) Molecular bases of viral RNA targeting by viral small interfering RNA-programmed RISC. J Virol 81:3797-3806. doi:10.1128/JVI.02383-06

Parizotto EA, Dunoyer P, Rahm N, Himber C, Voinnet O (2004) In vivo investigation of the transcription, processing, endonucleolytic activity, and functional relevance of the spatial distribution of a plant miRNA. Genes Dev 18:2237-2242. doi:10.1101/gad.307804

Parker JS (2010) How to slice: snapshots of Argonaute in action. Silence 1:3. doi:10.1186/1758-907X-1-3

Peragine A, Yoshikawa M, Wu G, Albrecht HL, Poethig RS (2004) SGS3 and SGS2/SDE1/RDR6 are required for juvenile development and the production of trans-acting siRNAs in Arabidopsis. Genes Dev 18:2368-2379. doi:10.1101/gad.1231804

Qu F, Ye X, Morris TJ (2008) Arabidopsis DRB4, AGO1, AGO7, and RDR6 participate in a DCL4-initiated antiviral RNA silencing pathway negatively regulated by DCL1. Proc Natl Acad Sci U S A 105: 14732-14737. doi:10.1073/pnas.0805760105

Renovell A, Vives MC, Ruiz-Ruiz S, Navarro L, Moreno P, Guerri J (2012) The Citrus leaf blotch virus movement protein acts as silencing suppressor. Virus Genes 44:131-140. doi:10.1007/s11262-011-0674-9

Rogers K, Chen X (2013) Biogenesis, turnover, and mode of action of plant microRNAs. Plant Cell 25:2383-2399. doi:10.1105/tpc.113. 113159

Roy G, Weisburg S, Foy K, Rabindran S, Mett V, Yusibov V (2011) Coexpression of multiple target proteins in plants from a Tobacco mosaic virus vector using a combination of homologous and heterologous subgenomic promoters. Arch Virol 156:2057-2061. doi:10. 1007/s00705-011-1069-x

Saenz P, Salvador B, Simon-Mateo C, Kasschau KD, Carrington JC, Garcia JA (2002) Host-specific involvement of the HC protein in the long-distance movement of potyviruses. J Virol 76:1922-1931

Saunders K, Lomonossoff GP (2013) Exploiting plant virus-derived components to achieve in planta expression and for templates for synthetic biology applications. New Phytol 200:16-26. doi:10.1111/ nph. 12204

Saxena P, Hsieh YC, Alvarado VY, Sainsbury F, Saunders K, Lomonossoff GP, Scholthof HB (2011) Improved foreign gene expression in plants using a virus-encoded suppressor of RNA silencing modified to be developmentally harmless. Plant Biotechnol J 9:703-712. doi:10.1111/j.1467-7652.2010.00574.x

Schnettler E, Hemmes H, Huismann R, Goldbach R, Prins M, Kormelink R (2010) Diverging affinity of tospovirus RNA silencing suppressor proteins, NSs, for various RNA duplex molecules. J Virol 84: 11542-11554. doi:10.1128/JVI.00595-10
Scholthof HB, Alvarado VY, Vega-Arreguin JC, Ciomperlik J, Odokonyero D, Brosseau C, Jaubert M, Zamora A, Moffett P (2011) Identification of an ARGONAUTE for antiviral RNA silencing in Nicotiana benthamiana. Plant Physiol 156:1548-1555. doi: 10.1104/pp. 111.178764

Schuck J, Gursinsky T, Pantaleo V, Burgyan J, Behrens SE (2013) AGO/ RISC-mediated antiviral RNA silencing in a plant in vitro system. Nucleic Acids Res 41:5090-5103. doi:10.1093/nar/gkt193

Segers GC, van Wezel R, Zhang X, Hong Y, Nuss DL (2006) Hypovirus papain-like protease p29 suppresses RNA silencing in the natural fungal host and in a heterologous plant system. Eukaryot Cell 5: 896-904. doi:10.1128/EC.00373-05

Sharma P, Ikegami M, Kon T (2010) Identification of the virulence factors and suppressors of posttranscriptional gene silencing encoded by Ageratum yellow vein virus, a monopartite begomovirus. Virus Res 149:19-27. doi:10.1016/j.virusres.2009.12.008

Shen WJ, Ruan XL, Li XS, Zhao Q, Li HP (2012) RNA silencing suppressor Pns11 of Rice gall dwarf virus induces virus-like symptoms in transgenic rice. Arch Virol 157:1531-1539. doi:10.1007/ s00705-012-1339-2

Siddiqui SA, Sarmiento C, Truve E, Lehto H, Lehto K (2008) Phenotypes and functional effects caused by various viral RNA silencing suppressors in transgenic Nicotiana benthamiana and N. tabacum. Mol Plant Microbe Interact 21:178-187. doi:10.1094/MPMI-21-2-0178

Soitamo AJ, Jada B, Lehto K (2011) HC-Pro silencing suppressor significantly alters the gene expression profile in tobacco leaves and flowers. BMC Plant Biol 11:68. doi:10.1186/1471-2229-11-68

Soitamo AJ, Jada B, Lehto K (2012) Expression of geminiviral AC2 RNA silencing suppressor changes sugar and jasmonate responsive gene expression in transgenic tobacco plants. BMC Plant Biol 12: 204. doi:10.1186/1471-2229-12-204

Stav R, Hendelman A, Buxdorf K, Arazi T (2010) Transgenic expression of tomato bushy stunt virus silencing suppressor P19 via the pOp/ LhG4 transactivation system induces viral-like symptoms in tomato. Virus Genes 40:119-129. doi:10.1007/s11262-009-0415-5

Sun QY, Ding LW, Lomonossoff GP, Sun YB, Luo M, Li CQ, Jiang L, Xu ZF (2011) Improved expression and purification of recombinant human serum albumin from transgenic tobacco suspension culture. J Biotechnol 155:164-172. doi:10.1016/j.jbiotec.2011.06.033

Sunkar R. (2012). MicroRNAs in plant development and stress responses. Springer

Szabo EZ, Manczinger M, Goblos A, Kemeny L, Lakatos L (2012) Switching on RNA silencing suppressor activity by restoring argonaute binding to a viral protein. J Virol 86:8324-8327. doi:10. 1128/JVI.00627-12

Takeda A, Iwasaki S, Watanabe T, Utsumi M, Watanabe Y (2008) The mechanism selecting the guide strand from small RNA duplexes is different among argonaute proteins. Plant Cell Physiol 49:493-500. doi:10.1093/pcp/pen043

Tolia NH, Joshua-Tor L (2007) Slicer and the argonautes. Nat Chem Biol 3:36-43. doi:10.1038/nchembio848

Valli A, Busnadiego I, Maliogka V, Ferrero D, Caston JR, Rodriguez JF, Garcia JA (2012) The VP3 factor from viruses of Birnaviridae family suppresses RNA silencing by binding both long and small RNA duplexes. PLoS ONE 7:e45957. doi:10.1371/journal.pone.0045957

Valli A, Oliveros JC, Molnar A, Baulcombe D, Garcia JA (2011) The specific binding to 21-nt double-stranded RNAs is crucial for the anti-silencing activity of Cucumber vein yellowing virus $\mathrm{P} 1 \mathrm{~b}$ and perturbs endogenous small RNA populations. RNA 17:1148-1158. doi:10.1261/rna.2510611

van Wolfswinkel JC, Ketting RF (2010) The role of small non-coding RNAs in genome stability and chromatin organization. J Cell Sci 123:1825-1839. doi:10.1242/jcs.061713

Vargason JM, Szittya G, Burgyan J, Hall TM (2003) Size selective recognition of siRNA by an RNA silencing suppressor. Cell 115: 799-811 
Vargason JM, Burch CJ, Wilson JW (2013) Identification and RNA binding characterization of plant virus RNA silencing suppressor proteins. Methods 64:88-93. doi:10.1016/j.ymeth.2013.08.016

Vaucheret H (2008) Plant ARGONAUTES. Trends Plant Sci 13:350358. doi:10.1016/j.tplants.2008.04.007

Várallyay E, Valoczi A, Agyi A, Burgyan J, Havelda Z (2010) Plant virus-mediated induction of miR168 is associated with repression of ARGONAUTE1 accumulation. EMBO J 29:3507-3519. doi:10. 1038/emboj.2010.215

Várallyay E, Havelda Z (2013) Unrelated viral suppressors of RNA silencing mediate the control of ARGONAUTE1 level. Mol Plant Pathol 14:567-575. doi:10.1111/mpp.12029

Várallyay E, Oláh E, Havelda Z (2014) Independent parallel functions of p19 plant viral suppressor of RNA silencing required for effective suppressor activity. Nucleic Acids Res 42:599-608. doi:10.1093/ nar/gkt846

Voinnet O, Vain P, Angell S, Baulcombe DC (1998) Systemic spread of sequence-specific transgene RNA degradation in plants is initiated by localized introduction of ectopic promoterless DNA. Cell 95: 177-187

Wang LY, Lin SS, Hung TH, Li TK, Lin NC, Shen TL (2012) Multiple domains of the Tobacco mosaic virus p126 protein can independently suppress local and systemic RNA silencing. Mol Plant Microbe Interact 25:648-657. doi:10.1094/MPMI-06-11-0155

Wang XB, Jovel J, Udomporn P, Wang Y, Wu Q, Li WX, Gasciolli V, Vaucheret H, Ding SW (2011) The 21-nucleotide, but not 22nucleotide, viral secondary small interfering RNAs direct potent antiviral defense by two cooperative argonautes in Arabidopsis thaliana. Plant Cell 23:1625-1638. doi:10.1105/tpc.110.082305

Wang XB, Wu Q, Ito T, Cillo F, Li WX, Chen X, Yu JL, Ding SW (2010) RNAi-mediated viral immunity requires amplification of virusderived siRNAs in Arabidopsis thaliana. Proc Natl Acad Sci U S A 107:484-489. doi:10.1073/pnas.0904086107

Wang Y, Juranek S, Li H, Sheng G, Wardle GS, Tuschl T, Patel DJ (2009) Nucleation, propagation and cleavage of target RNAs in Ago silencing complexes. Nature 461:754-761. doi:10.1038/nature08434

Weinheimer I, Boonrod K, Moser M, Wassenegger M, Krczal G, Butcher SJ, Valkonen JP (2014) Binding and processing of small dsRNA molecules by the class 1 RNase III protein encoded by Sweet potato chlorotic stunt virus. J Gen Virol 95:486-495. doi:10.1099/vir.0.058693-0

Wienholds E, Plasterk RH (2005) MicroRNA function in animal development. FEBS Lett 579:5911-5922. doi:10.1016/j.febslet.2005.07.070
Xian Z, Yang Y, Huang W, Tang N, Wang X, Li Z (2013) Molecular cloning and characterisation of S1AGO family in tomato. BMC Plant Biol 13:126. doi:10.1186/1471-2229-13-126

Yang X, Wang Y, Guo W, Xie Y, Xie Q, Fan L, Zhou X (2011) Characterization of small interfering RNAs derived from the geminivirus/betasatellite complex using deep sequencing. PLoS ONE 6:e16928. doi:10.1371/journal.pone.0016928

Ye J, Qu J, Zhang JF, Geng YF, Fang RX (2009) A critical domain of the Cucumber mosaic virus $2 \mathrm{~b}$ protein for RNA silencing suppressor activity. FEBS Lett 583:101-106. doi:10. 1016/j.febslet

Yelina NE, Savenkov EI, Solovyev AG, Morozov SY, Valkonen JP (2002) Long-distance movement, virulence, and RNA silencing suppression controlled by a single protein in hordei- and potyviruses: complementary functions between virus families. J Virol 76:12981-12991

Young BA, Stenger DC, Qu F, Morris TJ, Tatineni S, French R (2012) Tritimovirus P1 functions as a suppressor of RNA silencing and an enhancer of disease symptoms. Virus Res 163:672-677. doi:10. 1016/j.virusres.2011.12.019

Yu B, Chapman EJ, Yang Z, Carrington JC, Chen X (2006) Transgenically expressed viral RNA silencing suppressors interfere with microRNA methylation in Arabidopsis. FEBS Lett 580:31173120. doi:10.1016/j.febslet.2006.04.063

Yusibov V, Streatfield SJ, Kushnir N, Roy G, Padmanaban A (2013) Hybrid viral vectors for vaccine and antibody production in plants. Curr Pharm Des 19:5574-5586

Zhang B, Pan X, Cobb GP, Anderson TA (2006a) Plant microRNA: a small regulatory molecule with big impact. Dev Biol 289:3-16. doi: 10.1016/j.ydbio.2005.10.036

Zhang J, Dong J, Xu Y, Wu J (2012a) V2 protein encoded by Tomato yellow leaf curl China virus is an RNA silencing suppressor. Virus Res 163:51-58. doi:10.1016/j.virusres.2011.08.009

Zhang X, Yuan YR, Pei Y, Lin SS, Tuschl T, Patel DJ, Chua NH (2006b) Cucumber mosaic virus-encoded $2 \mathrm{~b}$ suppressor inhibits Arabidopsis Argonaute1 cleavage activity to counter plant defense. Genes Dev 20:3255-3268. doi:10.1101/gad.1495506

Zhang X, Zhang X, Singh J, Li D, Qu F (2012b) Temperaturedependent survival of Turnip crinkle virus-infected arabidopsis plants relies on an RNA silencing-based defense that requires dcl2, AGO2, and HEN1. J Virol 86:6847-6854. doi:10.1128/ JVI.00497-12 